\title{
IdeAs
}

Idées d'Amériques

$17 \mid 2021$

Villes et culture dans les Amériques

\section{Americanism in France: institutions and current trends}

Robert Boyer and François-Michel Le Tourneau

\section{(2) OpenEdition}

1 Journals

Electronic version

URL: https://journals.openedition.org/ideas/10576

DOI: 10.4000/ideas.10576

ISSN: 1950-5701

Publisher

Institut des Amériques

Electronic reference

Robert Boyer and François-Michel Le Tourneau, "Americanism in France: institutions and current trends", IdeAs [Online], 17 | 2021, Online since 01 March 2021, connection on 03 June 2021. URL: http://journals.openedition.org/ideas/10576 ; DOl: https://doi.org/10.4000/ideas.10576

This text was automatically generated on 3 June 2021

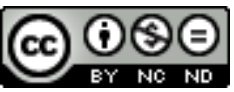

IdeAs - Idées d'Amériques est mis à disposition selon les termes de la licence Creative Commons Attribution - Pas d'Utilisation Commerciale - Pas de Modification 4.0 International. 


\title{
Americanism in France: institutions and current trends
}

\author{
Robert Boyer and François-Michel Le Tourneau
}

1 The study of the Americas, or "Americanism", appeared as a specific area or specialty in French universities from the middle of the $19^{\text {th }}$ century. It built on deep-going roots about the specificity of the American continent and on the importance of its "discovery" in the intellectual history of Europe, providing a kind of anti-model of what was considered "civilization" and a general interrogation about models of "nature" and "society". After a slow start, which included however very important steps $^{1}$, the institutionalization of this field took place after the Second World War.

2 The objective of this paper is to provide a brief survey of how this consolidation took place in the French academic world, laying out bases that still explain the state of American studies in France today. This institutional prism does not preclude either a study of popular interest or other analyses, especially about the different theories and currents which have gone through or emerged in French Americanism. However, as the space of a single paper is not enough to treat all these points, we chose to focus here on the institutional aspect.

\section{After World War 2, two distinct South/North trajectories}

3 It was at this time when Americanism really started to grow in French academia ${ }^{2}$ under the influence of intellectuals who had started their careers in the Americas during the 1930s and those (sometimes the same) who had fled the persecution by the Vichy regime and were harbored by the Free School of High Studies in New York. The Maison de l'Amérique latine was thus created in 1945, followed in 1947 by the $6^{\text {th }}$ section of the Ecole Pratique des Hautes Etudes (EPHE), with three chairs about religions in the Americas, which hosted scholars such as Pierre Clastres and Patrick Menget. At that time, France also reinitiated its policy of cultural influence, creating research centers in Haiti (1945), the Andes (1948) and in Mexico (1945 and $\left.1962^{3}\right)$, the latter two largely devoted to 
archeological studies first and then expanding to other disciplines. In 1954 the Institut des Hautes Études d'Amérique latine (IHEAL) was created in Paris and installed in a building in Front of the Ecole libre des Sciences politiques two years later. Its library ${ }^{4}$ grew quickly to become the first French and one of the first European libraries specialized in Latin and South America. This move was echoed outside the capital by the creation of the Institut d'études hispano-américaines in Toulouse (1959). No corresponding center specialized on North America or the United States was created, however.

4 The "model" initiated in Brazil during the 1930s - young French academics being offered long stays in the Americas to develop their research and strengthen ties with the host country - was replicated during the 1950s and 1960s. In 1956 the Chilean Mission (equivalent to the one sent to Brazil in the 1930s) started, with professors like Lucien Brams and Alain Touraine. Other academics accomplished long stays in Latin America, like Olivier Dollfus, in Peru, Jean Bordes, in Chile, Romain Gaignard, in Argentina, Claude Bataillon, in Mexico, among others. Even if numerous French scholars have taught on US campuses at the invitation of American universities, the dynamics with North America has been largely different, with a policy of active influence (under the idea of soft power) by the US government which provided important support to French university libraries and North American studies, and funded, in partnership with the French government, the Fulbright program started in 1948.

5 Accompanying the structuration of the field of American studies, here were growing numbers of University chairs devoted to American studies. In 1967 Frederico Mauro inaugurated the Chair of Latin American studies at Nanterre University and the following year Claude Fohlen opened a chair of North American history at the Sorbonne, later occupied by André Kaspi. In 1970 a chair of Latin American studies was opened at the Sorbonne by François Chevalier. After that time, the rapid expansion of universities in France and the breakup of most universities into several parts in order to accommodate the exponential growth of students and demand for higher education, led to the multiplication of chairs specialized in the Americas, many of them in the departments of literature, languages and cultural studies, often labelled as "civilization" (a French denomination often used in France for area or cultural studies). Also in the 1960s and 1970s several academic journals specialized in the Americas started to appear, like Caravelle (1963), Problèmes d'Amérique latine (1967), Cahiers des Amériques latines (1968) and later on l'Ordinaire du Mexicaniste (1974) and Études canadiennes (1975), Revue française d'Etudes américaines (1976). Most of them are still being published and represent important institutions of Americanism in France.

6 The particular interest by French academics for South America and lesser structuration of the research on the Northern part may be interpreted in different ways. One can see in it the influence of the socialist movement among French intellectuals and the popular fascination for figures like Fidel Castro or Che Guevara, or the contestation of US imperialism symbolized by the Vietnam war - anti-Americanism has a long and rich history in France ${ }^{5}$ (Roger, P. 2002). When looking at the North, French intellectuals were, for most of them, keener to work on Canada than on the United States. The influence of the United States has nonetheless existed, especially through the funding of French academics' missions and research by foundations like Rockefeller or Ford Foundations, or by bilateral institutions such as the already mentioned Fulbright 
program, resulting in strong personal ties and person to person international collaborations which are not necessarily tied to institutional strategies. Interestingly enough, the program of the CERI research center devoted to Latin America, started in 1966, and in which academics like Alain Rouquié intervened, was funded by the Ford Foundation.

7 The chronology of the consolidation of research centers devoted to the Americas closely follows the institutionalization of Americanism in the universities that has proven to be different for the South and the North.

Early research centers specialized on South or Latin America appeared in the 1960s, like the CEPES which was transformed into the Centre de Recherche et de Documentation de l'Amérique latine (CREDAL) years later, the Centre de Recherche d'Histoire de l'Amérique latine et du Monde Ibérique (CHRAMLI, Paris 1 University, 1970), the Groupe de Recherche en Sciences sociales de l'Amérique Latine (GRESAL, Grenoble University, 1975), the Centre d'études canadiennes (Bordeaux University, 1975) and the Équipe de Recherche en Ethnologie Amérindienne (EREA, EHESS, 1977). In the EHESS, two centers, one about Mexico and another about Brazil were created in the 1980s (CERMACA directed by Nathan Wachtel and Serges Gruzinski and CRBC created by Afrânio Garcia and Ignacy Sachs). Outside of Paris, the Groupe de Recherche sur l'Amérique latine (GRAL) was created in Toulouse by Claude Bataillon at the end of the 1970s and turned into the Institut pluridisciplinaire d'étude de l'Amérique latine in 1985.

Centers specialized on North America were longer to appear. For instance, even though its program of area studies had been created by François Furet in 1956, it was only in 1980 that the EHESS created the Centre d'études Nord-Américaines (CENA), directed by Jean Heffer. This was echoed by the creation of the Centre de recherches d'histoire nordaméricaine (CRHNA) by Claude Fohlen at University Paris 1, which also initiated a center for Canadian research in 1988. The CRHNA operates the largest library specialized on North American studies in France.

10 Most of these research centers dedicated to the Americas are focused on social sciences, mainly history, anthropology, sociology, archeology, etc. In economy as in some other disciplines like political science, however, the approach of the Americas has more often been embedded in general theories, which may explain why there are almost no centers specialized in this area.

11 Research is supported by several associations. The Association Française d'Études Américaines (AFEA), for instance, was created in 1968 as a link between academics interested in English literature in North America. It has since expanded to encompass many other topics, following the evolution of "civilization" studies. In 1976, the Association Française d'Études Canadiennes - AFEC was created, centered, as the name indicates, on Canadian studies ${ }^{6}$.

12 Finally, the French academic centers located in overseas territories must be acknowledged. In 1982, external campuses linked with Bordeaux University were created, transformed into a full-fledged university in 1994. In 2014, the campus of French Guiana also turned autonomous, and there is therefore currently one university for the French Caribbean and one in French Guiana. Research centers were created in parallel, like the Centre Pouvoirs Locaux dans la Caraibe established in 1982. 


\section{A North-South convergence since 2000}

divide of French Americanism. Research centers or university departments have thus opened their areas of interest to the entirety of the American continent, like the IPEALT of Toulouse or the CREDA. Their names frequently changed to echo this move, now referring to "Americas". Also, several centers have regrouped in order to gain critical mass and be more attractive for students and faculty. At EHESS, for instance, the center named "Mondes américains" (American worlds) was created in 2006 by grouping five centers specialized on North America, Brazil, Mexico. Among the veteran institutions, CREDA and "Mondes américains" are two of the four CNRS associated research labs which have the Americas as their principal research focus (the CRPLC, focused on the Caribbean and the archeology research centrer Archam are the two other ones). Several of these new centers join several distinct universities, echoing the global policy of the French government to incentive regrouping of French academic centers into larger entities. One must also mention the specificity of INALCO University, which is one of the rare places in the world to offer language courses for minority North-American (Inuktitut) Meso-American (Nahuatl, Tzeltal, Yucateque) or South American languages (Guarani).

Finally, new institutions emerged, like the two regional campuses of Sciences Po specialized on Latin America (Poitiers) and on North America (Reims), and research networks like the Rennes Institut des Amériques (2003) and, at the national level, the Institut des Amériques IdA (2006). The emergence of the latter is particularly worth noting. Instead of being a new structure inside a specific university, it was created as a network of research centers from all French universities and colleges on a voluntary basis. In 2021 IdA is composed of 55 universities spanning the whole French territory (including overseas departments). Since 2019, it has joined the Campus Condorcet, a new infrastructure located north of Paris offering a national platform for Human and Social Sciences in France. IdA also operates 12 units in the Americas. A new landscape thus emerged for Americanism in the 2000s, with older structures still present but sometimes reconfigured to encompass both North and South Americas, and new players.

ting this panorama of French Americanism, the directory compiled in 2016 by IdA gives a snapshot of how this field is now consolidated in France. The directory lists about 1,000 French academics whose research or teaching is mostly concerned with the Americas. About $90 \%$ of them are university faculty and $10 \%$ of them are full time researchers from CNRS and IRD. About 51.8\% are women, but female faculties are in greater number in junior ranks and fewer in senior ranks. This is however changing relatively fast, as the $57.4 \%$ of junior female faculty are advancing their careers.

The proportion of faculty studying North or South or Latin America is more balanced than one could expect given the history of Americanism in France. Even if they did not create larger and more visible research center, scholars studying North America have claimed an even place in universities. This is largely due to the fact that the largest number of faculty listed in the directory come from the area of languages, cultural studies and civilization, and reflects the influence/popularity? and importance of English-speaking world studies. 259 faculty thus teach in literature departments (143 for English and the rest for Spanish and Portuguese) and 224 in Cultural studies (148 
about North America). History and geography are the other disciplines with the largest number of faculty. Combined, literature, cultural studies, history and geography amount to $71,5 \%$ of all the directory. Sociology, political science or economics are very little represented, which reflects the institutional dynamics of French Americanism, which is stronger within disciplines which easily embrace the notion of area studies and weaker in those which favor global approaches.

The apparent balance between North and South/Latin America ceases when it comes to full time researchers from the CNRS and IRD, with $71 \%$ of them working on the latter. This is partly, but not entirely, due to the fact that the IRD is specialized in research on development and thus inherently focused on the Global South. The largest mass of faculty works in Paris, with about 400 people, whereas other cities do not group more than 60 Americas-focused faculty.

French Americanism has strong ties with Latin American scholars, especially because many sought refuge in France during the period of military regimes in Brazil, Argentina of Chile. Pursuing this legacy, eleven chairs are specifically dedicated to hosting academics from South America across France, especially in the IHEAL or IPEALT. French Americanism can also count on the research centers located in the Americas, which are still operating under the umbrella of the Foreign Affairs Ministry and/or CNRS and IRD (see map). If France still maintains a strong research dispositive overseas, with a stronger focus on Latin America, the US governmental support for North American studies in France has dwindled, being today reduced mainly to the Fulbright commission and occasional funding by the US embassy.

\section{New frontiers of research}

If regional and local studies and monographies have been the staple of French Americanism, new trends seem to appear in research. First of all, after decades highlighting local particularisms, more and more studies are looking at TransAmerican topics and under a comparatist perspective, like environmental issues, the dynamics between free trade and protectionism, gender issues, inequality issues, minorities, risks, drugs, etc. Moreover, several disciplines are seeing the emergence of new tools (DNA analyses and lidar in archeology, high resolution remote sensing and GIS in geography, databases and datamining for digital humanities, etc.) which allow to take a fresh look at older problematics and can lead to complete paradigm changes. This is for instance the case in Amazonian archeology, where new capacities have led to question to old paradigm of the impossibility of large settlements in the rainforest and to point out, on the contrary, the abundance of large villages and the precocity of human settlement in this region.

In several fields, like history or literature, the transatlantic perspective has also been increasingly explored, as well as the question of mutual circulation of people and ideas between Europe and the Americas. Finally, inter- or trans-disciplinarity also appears more and more strongly within French Americanism. This way has been paved, as we mentioned, by "civilization" departments in several universities where the study of language and literature was often complemented with history. Nowadays, multidisciplinary research projects are coming forward, bringing several disciplines together, like history and sociology or anthropology, or geography and anthropology, etc. This is not a complete innovation since ethnohistory, anthropological history or 
geo-history are currents with a long history inside French academia and especially in French Latino-Americanism.

The diversity and extent of research in French Americanism echoes a genuine public interest in the American continents, which appears clearly through newspapers or with some specialized magazines such as the quarterly America, for instance. Scholars are regularly invited on TV or radio broadcast to explain the dynamics of American countries, decipher elections and social, economic and sanitary crises. Much remains to be done, however, both to convey to this audience the real results of research and to dissipate long standing clichés that still persist, despite - or perhaps because of - more than one and a half century of Americanism in France, in French universities and research centers.

\section{NOTES}

1. Livre Blanc de l'Américanisme en France, Paris, Institut des Amériques, 2017.

2. Chonchol, Martinière, L'Amérique latine et le latino-américanisme en France, Paris, L'Harmattan, 1985.

3. A French Institute for Latin American studies was created in 1945 and an Archeological mission in 1962.

4. Later named Bibliothèque Pierre Monbeig in the name of the founder of the IHEAL.

5. Roger, L'ennemi américain, Paris, Seuil, 2002.

6. Lacroix, "Canadian Studies in France" in S. Brooks, Promoting Canadian Studies Abroad. Soft Power and Cultural Diplomacy, Palgrave Macmillan, 2019, p. 97-128.

\section{AUTHORS}

\section{ROBERT BOYER}

Robert Boyer a été directeur de recherche au CNRS et Directeur d'Etudes à l'EHES. Il est chercheur rattaché à l'Institut des Amériques, Paris. Au titre de la théorie de la régulation, il a développé une analyse historique et comparative des transformations institutionnelles des capitalismes et de leur interdépendance au sein d'un régime international en crise. Parmi ses publications Economie politique des capitalismes, La Découverte 2015 et Les capitalismes à l'épreuve de la pandémie, La Découverte, 2020. Pour plus d'informations consulter http://robertboyer.org.

\section{FRANÇOIS-MICHEL LE TOURNEAU}

François-Michel Le Tourneau est directeur de recherche au CNRS et directeur-adhoint de l'UMI iGLOBES (CNRS-ENS-Université d'Arizona). 